\title{
Gambaran Kecerdasan Emosional Mahasiswa Prodi D-III Kebidanan dan Program Studi Sarjana Terapan Berlanjut Pendidikan Profesi Bidan
}

\author{
Triwik Sri Mulati ${ }^{1 *}$ \\ Poltekkes Kemenkes Surakarta, Jurusan kebidanan \\ *Email : triwiksrimulati@gmail.com
}

\begin{abstract}
Background: Psychological theory reveals that emotional intelligence influences human behavior. One of them is student behavior in the learning process will be influenced by the emotional intelligence he has. With good emotional intelligence, students tend to be more responsible in carrying out their roles as students. But in fact, not many teaching staff at the Educational Institution pay attention to the teori about the importance of emotional intelligence, whereas if emotional intelligence is developed in an educational institution it will optimize student responsibility, behavior and learning achievement. Aims study to describe the emotional intelligence of students of the Department of Midwifery Diploma Program and Continued Applied Bachelor Study Program Professional Education Midwife Professional Program in the Midwifery Department of the Polytechnic of the Ministry of Health Surakarta. The results of this study are expected to be used as an additional reference and input to teaching staff, especially in the Surakarta Health Polytechnic and Education Institutions in general to develop emotional intelligence in order to increase student responsibility, behavior and learning achievement. Methods: This type of research is descriptive. Univariate data analysis uses frequency distribution. Results: The level of emotional intelligence in midwifery DIII program is quite good $98.8 \%$ and good $1.2 \%$. The level of emotional intelligence in midwifery applied bachelor is quite good 52.7\%, good 44.9\%, and very good $2.7 \%$. Conclusion: Most midwifery students have good emotional intelligence.
\end{abstract}

Keywords: emotional intelligence, midwifery DIII students, applied undergraduate students continued midwifery professional education

\section{PENDAHULUAN}

Teori psikologi mengungkapkan bahwa kecerdasan emotional berpengaruh terhadap perilaku manusia. Salah satunya perilaku mahasiswa di dalam proses pembelajaran akan dipengaruhi oleh kecerdasan emosional yang dia miliki. Kecerdasan emosional yang baik, mahasiswa cenderung akan lebih bertanggung jawab dalam menjalankan perannya sebagai mahasiswa. Faktanya belum banyak staf pengajar di instusi pendidikan memberi perhatian pada teori tentang pentingnya kecerdasan emosional, padahal jika kecerdasan emosional dikembangkan di institusi pendidikan akan mengoptimalkan tanggung jawab, perilaku dan prestasi belajar mahasiswa.

Berdasarkan penelitian yang telah dilakukan oleh Wahyuningsih, A.S (2004) tentang antara kecerdasan emosional dengan prestasi belajar pada siswa kelas II SMU LAB School Jakarta Timur didapatkan hasil nilai koefisien korelasi sebesar 0,248 dengan $\mathrm{p}=0,002(0,05)$ sehingga dapat disimpulkan ada hubungan antara kecerdasan emosional dengan prestasi belajar pada siswa kelas II Kelas II SMU LAB School Jakarta Timur.

Istilah kecerdasan emosional pertama kali dilontarkan pada tahun 1990 oleh psikolog Peter Salovey dari Harvard University dan John Mayer dari University of New Hampshire untuk menerangkan kualitas-kualitas emosional yang tampaknya penting bagi keberhasilan. Solvey dan Mayer mendefinisikan kecerdasan emosional sebagai himpunan bagian dari kecerdasan sosial yang 
melibatkan kemampuan memantau perasaan sosial yang melibatkan kemampuan pada orang lain, memilahmilah semuanya dan menggunakan informasi ini untuk membimbing pikiran dan tindakan (Shapiro, 1998).

Sementara itu Goleman (1997) mengungkapkan lima wilayah kecerdasan emosional yang dapat menjadi pedoman bagi individu untuk mencapai kesuksesan dalam kehidupan sehari-hari yaitu: mengenali emosi diri, mengelola emosi, mengenali emosi orang lain, membina hubungan dengan orang lain dan memotivasi diri, termasuk memotivasi diri untuk belajar.

Kecerdasan emosional menuntut diri untuk belajar mengakui dan menghargai diri sendiri dan orang lain dan untuk menanggapi dengan tepat, menerapkan dengan efektif energi dan emosi dalam kehidupan. Kecerdasan emosional adalah kemampuan untuk mengenali emosi diri, mengelola emosi diri, memotivasi diri sendiri, mengenali orang lain (empati), dan kemampuan untuk membina hubungan dengan orang lain.

Dari survey pendahuluan yang telah dilakukan peneliti didapatkan data bahwa selama ini mahasiswa Jurusan Kebidanan belum di gali kecerdasan emosional nya. Padahal dengan tergalinya kecerdasan emosional mahasiswa akan dapat meningkatkan kualitas proses belajar mengajar. Oleh karena itu perlunya sebuah penelitian yang bertujuan untuk menggali kecerdasan emosional mahasiswa baru. Dengan dikenalinya kecerdasan emosional mahasiswa baru Jurusan Kebidanan maka akan membantu para staf pengajar untuk memaksimalkan proses belajar mengajar di Jurusan Kebidanan.

Dosen di jurusan kebidanan sebaiknya juga memberi sentuhan pada ranah afektif mahasiswa dengan mengembangkan kecerdasan emosional mahasiswa. Berdasarkan teori psikologi, kecerdasan emosional yang meningkat, akan meningkatkan tanggung jawab, perilaku dan prestasi belajar mahasiswa.

Penelitian ini bertujuan untuk menggambarkan kecerdasan emosional mahasiswa Prodi DIII Kebidanan dan Prodi Sarjana terapan berlanjut Pendidikan Profesi Bidan Program Profesi Jurusan Kebidanan Poltekkes Kemenkes Surakarta.

\section{METODE PENELITIAN}

Jenis penelitan ini adalah diskriptif, dengan pendekatan cross sectional. Sampel pada penelitian ini adalah 83 mahasiswa prodi DIII Kebidanan dan 74 mahasiswa Prodi Sarjana Terapan berlanjut Pendidikan Profesi Bidan Program Profesi Jurusan Kebidanan Poltekkes Kemenkes Surakarta yang diambil dengan menggunakan tehnik random sampling. Data kecerdasan emosional di ambil dengan cara menyebarkan kuesionare tentang kecerdasan emosional yang telah baku yang diisi oleh seluruh responden.

\section{HASIL PENELITIAN}

Hasil penelitian menunjukkan distribusi kecerdasan emosional mahasiswa sebagai berikut: 
Tabel 1. Distribusi Frekuensi Kecerdasan Emosional Mahasiswa Prodi DIII Kebidanan Jurusan Kebidanan

\begin{tabular}{|c|c|c|}
\hline Kecerdasan Emosional & Frekuensi & Persentase (\%) \\
\hline Sangat baik & 0 & 0 \\
\hline Baik & 1 & 1,2 \\
\hline Cukup baik & 82 & 98,8 \\
\hline Kurang & 0 & 0 \\
\hline Total & 83 & 100 \\
\hline
\end{tabular}

Berdasarkan tabel 1. mayoritas kecerdasan Kebidanan Jurusan Kebidanan adalah emosional mahasiswa Prodi DIII cukup baik sejumlah 82 orang $(98,8 \%)$.

Tabel 2. Distribusi Frekuensi Kecerdasan Emosional Mahasiswa Prodi Sarjana Terapan berlanjut Pendidikan Profesi Bidan Jurusan Kebidanan

\begin{tabular}{|c|c|c|}
\hline Kategori & Frekuensi & Persentase \\
\hline Sangat baik & 2 & 2.7 \\
\hline Baik & 33 & 44.9 \\
\hline Cukup baik & 39 & 52,7 \\
\hline Kurang & 0 & 0 \\
\hline Total & 74 & 100 \\
\hline
\end{tabular}

Berdasarkan tabel 2. Mayoritas profesi Bidan adalah cukup baik sejumlah kecerdasan emosional mahasiswa Prodi Sarjana Terapan berlanjut Pendidikan

\section{PEMBAHASAN}

Dari hasil penelitian kecerdasan emosi pada mahasiswa Prodi DIII Kebidanan sejumlah 83 responden menunjukkan bahwa mayoritas memiliki kecerdasan emosional cukup baik sejumlah 82 orang $(98,8 \%)$. Dari hasil penelitian kecerdasan emosional pada mahasiswa Prodi Sarjana Terapan berlanjut Pendidikan Profesi Bidan Program Profesi Jurusan Kebidanan sejumlah 74 responden menunjukkan bahwa mayoritas memiliki kecerdasan emosional cukup baik sejumlah 39 orang $(52,7 \%)$.

Hal tersebut diatas terjadi karena beberapa sebab. Kemungkinan penyebabnya antara lain dari latar belakang pola pengasuhan orang tua dan lingkungan sekitar karena dua hal tersebut

akan sangat berpengaruh terhadap pembentukan kecerdasan emosional seseorang. Jika pola pengasuhan orang tua dan lingkungan sekitar yang baik maka akan membentuk kecerdasan sesorang yang baik pula. Tapi jika pola pengasuhan orang tua dan lingkungan sekitar yang kurang baik maka juga akan membentuk kecerdasan emosional yang cenderung kurang baik.

Teori tentang kecerdasan emosional mengungkapkan bahwa mengenali emosi diri sendiri merupakan suatu kemampuan untuk mengenali perasaan sewaktu perasaan itu terjadi. Kemampuan ini merupakan dasar dari kecerdasan emosional. Para ahli psikologi menyebutkan kesadaran diri sendiri sebagai metamood, yaitu kesadaran 
seseorang akan emosinya sendiri. Menurut Goleman (2002:64), kesadaran diri adalah waspada terhadap suasana hati maupun pikiran tentang suasana hati, bila kurang waspada maka individu menjadi mudah larut dalam aliran emosi dan dikuasai oleh emosi. Kesadaran diri memang belum menjamin penguasaan emosi, namun merupakan salah satu prasyarat penting untuk mengendalikan emosi sehingga individu mudah menguasai emosi.

Mengelola emosi merupakan kemapuan individu dalam menangani perasaan agar dapat terungkap dengan tepat atau selaras, sehingga tercapai keseimbangan dalam diri. Menjaga emosi tetap terkendali merupakan kunci menuju kesejahteraan emosi. Kemampuan untuk menghibur diri sendiri, melepaskan kecemasan, kemurungan dan ketersinggungan dan akibat yang ditimbulkan serta kemampuan untuk bangkit dari perasaan tertekan merupakan kemampuan mengelola emosi diri.

Kecerdasan emosional dipengaruhi oleh lingkungan, tidak bersifat menetap, dapat berubah-ubah setiap saat. Peranan lingkungan terutama orang tua pada masa kanak-kanak sangat mempengaruhi dalam pembentukan kecerdasan emosional. Kecerdasan emosional tidak begitu dipengaruhi oleh faktor keturunan (Shapiro,1998).

Pendapat lain tentang kecerdasan emosional disampaikan oleh Goleman (2002:512), kecerdasan emosional adalah kemampuan seseorang mengatur kehidupan emosinya dengan intelegensi (to manage our emotional life with intelligence), menjaga keselarasan emosi dan pengungkapannya (the apporopriateness of emotion and its expression) melalui ketrampilan kesadaran diri, pengendalian diri, motivasi diri, empati dan ketrampilan sosial.

Dari berbagai pendapat yang dikemukakan di atas dapat dikatakan bahwa kecerdasan emosional menuntut diri untuk belajar mengakui dan menghargai diri sendiri dan orang lain dan untuk menanggapi dengan tepat, menerapkan dengan efektif energi dan emosi dalam kehidupan. Kecerdasan emosional adalah kemampuan untuk mengenali emosi diri, mengelola emosi diri, memotivasi diri sendiri, mengenali orang lain (empati), dan kemampuan untuk membina hubungan dengan orang lain.

Pada penelitian ini, responden rata rata berusia 18 - 19 tahun yang masih memiliki kecerdasan emosional yang cukup karena kurangnya pengalaman dalam memanagemen emosi sehingga gambaran kecerdasan emosinya mayoritas hanya cukup baik dimana kemampuan untuk mengenali emosi diri, mengelola emosi diri, memotivasi diri sendiri, mengenali orang lain (empati), dan kemampuan untuk membina hubungan dengan orang lain hanya cukup baik.

\section{KESIMPULAN DAN SARAN}

Berdasarkan hasil penelitian dapat disimpulkan kecerdasan emosional mahasiswa Prodi DIII Kebidanan dan Prodi Sarjana terapan berlanjut Pendidikan Profesi Bidan Program Profesi Jurusan Kebidanan Poltekkes Kemenkes Surakarta mayoritas cukup baik. Mahasiswa dapat mengembangkan kecerdasan emosionalnya. , dan pengajar dapat mengembangkan kecerdasan emosional para mahasiswa. 


\section{DAFTAR RUJUKAN}

Arikunto,S. (2002). Prosedur Penelitian Suatu Pendekatan Praktek, Jakarta : Rineka Cipta

Departemen Kesehatan. (2002). Kurikulum Pendidkan Diploma III Kebidanan, Jakarta

Goleman, D. (2002). Emitional Intelligence (terjemahan). Jakata : PT Gramedia Pustaka Utama.

Goleman, D. (2000). Working With Emotional Intelligence (terjemahan). Jakarta : PT. Gramedia Pustaka Utama.

Hakim,T. (2001). Belajar Secara Efektif, Jakarta : Puspa Swara.
Supartini. (2008). Hubungan Motivasi Belajar dengan Hasil Belajar di SMK Al Hidayah I Jakarta Selatan, Skripsi STKIP Purnama Jakarta.

Tjundjing, S. (2001). Hubungan Antara IQ, EQ, dan QA dengan Prestasi Studi Pada Siswa SMU. Jurnal Anima Vol.17 no.1

Purwanto,N. (2004). Psikolog Pendidikan, Bandung : PT Remaja Rosdakarya

Wahyuningsih. (2004). Hubungan Antara Kecerdasan Emosional dengan Prestasi Belajar pada Siswa Kelas II SMU Lab School Jakarta Timur, Skripsi, Fakultas Psikologi Universitas Persada Indonesia Jakarta 